\title{
Usage of Modern Applications for E-Recruitment Process in Private Firms
}

\author{
W.Porselvi, Sumathi Arjunan, M.M.Shanmuga Priya
}

\begin{abstract}
Fruitful enlistment practices are key segments at the passage purpose of HR in any association. Productive enlistment methodologies bring about improved association results. The principle target of this paper is to distinguish general practices that association use to enlist representatives. The investigation additionally concentrate to decide how the enlistment practices influence the association results. The information was gathered through very much organized poll. The wellspring of information was both essential and optional and the example size was 110. Information examination has been finished with measurable apparatuses.
\end{abstract}

Key words: Experience, qualification, external recruitment, internal recruitment, written test, group discussion, interview.

\section{INTRODUCTION}

Human resource is centrality for the accomplishment of any association. HR are the bounty of any affiliation which helpers in achieving the goal of the affiliation. It reflects another point of view which reviews affiliation work as its advantage and assets. Enlistment is indisputable from work and assurance. At the point when the fundamental number and kind of human resource are settled, the organization as to find the spots where they require human resource are/will be available and moreover find the techniques attracting them towards the relationship before decision sensible contender for occupations. This strategy is generally know as enlistment. A couple of individuals use the articulation "Enlistment" for work. These tows are not one and the identical. Enrollment is only one of the methods in the substance work process. [1]-[5]

Some other use the term selection and decision. These are not the equal either really, the limit of enlistment goes before the decision limit and it consolidate simply finding, developing the wellspring of arranged specialists and attracting them to follow positions in an affiliation, where as the assurance is system of finding the most contender to the action out of the contenders required. Enrolling a specialist by first understanding the exact silk set and subsequently organizing it with the diverse applicant's resume and a while later short postings and screening the best fit out of the part is what is required. Understanding and choosing segment like guidance establishment affirmations capacities and region kind of industry work understanding, etc for obtaining or enlisting a right capable.

Revised Manuscript Received on December 30, 2019.

W.Porselvi , Assistant Professor, Department Of Science and Humanities, Bharath Institution Of Higher Education And Research, TamilNadu, India Email: porselviwilson@gmail.com

Sumathi Arjunan, Assistant Professor, Department Of Science and Humanities,Bharath Institution Of Higher Education And Research TamilNadu,India. Email: sumi.renu@gmail.com

M.M.Shanmuga Priya, Assistant Professor, Department Of Science and Humanities,Bharath Institution Of Higher Education And Research TamilNadu,IndiaEmail: priyashammu@gmail.com

\section{NEED FOR THE STUDY}

- To think about the enlistment procedure.

- To study the HR polices and the working of HR office.

- To study how the opportunities are cleared and on what base the up-and-comers are enlistment for a specific employment.

- To recognize and recommend measures for the improvement of the enlistment programs.

- To learn about the enlistment techniques.

- To assess the enrollment the executives programs

\section{OBJECTIVES OF THE STUDY}

Primary objectives

- To study of effectiveness of recruitment process at "Yoho technologies pvt ltd".

\section{Secondary objectives}

- To analysis the satisfaction level of employees towards selection interview and some key consideration while interview.

- To find out the opinion of employees towards the training after final interview and offer letter procedure.

- To find whether the recruitment procedures and policies are satisfied by the employees.

\section{RESEARCH METHODOLOGY}

Research Design :Descriptive Research

Sample Size $\quad: 110$

Data Collection Method :Primary Data, Secondary Data

\section{RESULTS AND DISCUSSIONS}

\section{i. Chi-Square Test}

$\mathrm{Ho}=$ There is no significant different between the year of experience of employees with respected to the opinion about the present method followed by organization.

$\mathrm{H} 1=$ There is significant different between the year of experience in employees with respected to enhance the opinion about the present method followed by organization.

Chi-square test association difference between the year of experience inemployees with respected to enhance the opinion about the present method followed by organization.

Sample chi-square $\left.\left(\mathbf{x}^{2}\right)=\sum \underline{(0}_{1}-\underline{F}_{4}\right)^{2}$

$\mathrm{E}_{4}$ 


\begin{tabular}{|c|c|c|c|c|c|c|}
\hline \multicolumn{7}{|c|}{ Case Processing Summary } \\
\hline & \multicolumn{6}{|c|}{ Cases } \\
\hline & \multicolumn{2}{|c|}{ Valid } & \multicolumn{2}{|c|}{ Missing } & \multicolumn{2}{|l|}{ Total } \\
\hline & $\mathrm{N}$ & Percent & $\mathrm{N}$ & Percent & $\mathrm{N}$ & Percent \\
\hline 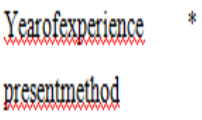 & 110 & $99.1 \%$ & 1 & $0.9 \%$ & 111 & $100.0 \%$ \\
\hline
\end{tabular}

\section{Chi-Square Tests}

\begin{tabular}{|l|l|l|l|}
\hline & Value & df & $\begin{array}{l}\text { Asymp. Sig. } \\
(2 \text {-sided })\end{array}$ \\
\hline Pearson Chi-Square & $12.539^{\mathrm{a}}$ & 9 & .185 \\
\hline Likelihood Ratio & 14.824 & 9 & .096 \\
\hline $\begin{array}{l}\text { Linear-by-Linear } \\
\text { Association }\end{array}$ & 1.276 & 1 & .259 \\
\hline N of Valid Cases & 110 & & \\
\hline
\end{tabular}

a. 7 cells $(43.8 \%)$ have expected count less than 5 . The minimum expected count is .57 .

\begin{tabular}{|c|c|c|c|c|c|c|}
\hline \multicolumn{7}{|c|}{ Yearofexperience * presentmethodCrosstabulation } \\
\hline \multicolumn{7}{|l|}{ Count } \\
\hline & & \multicolumn{4}{|c|}{ Presentmethod } & \multirow[t]{2}{*}{ Total } \\
\hline & & $\begin{array}{l}\text { highly } \\
\text { satisfied }\end{array}$ & satisfied & dissatisfied & $\begin{array}{l}\text { highly } \\
\text { dissatisfied }\end{array}$ & \\
\hline \multirow{4}{*}{$\begin{array}{l}\text { Yearofexperien } \\
\text { ce }\end{array}$} & $0-2$ years & 18 & 8 & 6 & 0 & 32 \\
\hline & $3-5$ years & 14 & 14 & 11 & 4 & 43 \\
\hline & $6-8$ years & 12 & 8 & 5 & 1 & 26 \\
\hline & 8 above & 3 & 4 & 0 & 2 & 9 \\
\hline \multicolumn{2}{|l|}{ Total } & 47 & 34 & 22 & 7 & 110 \\
\hline
\end{tabular}

\section{Interpretation}

The worth is essentialness (2-followed) is 0.185 which lesser than 0.05 at $95 \%$ certainty level so dismiss the invalid speculation (H0) and acknowledge the substitute theory (H1). There is affiliation contrast between the age gathering of workers as for upgrade the sentiment about the present technique pursued by the association.

\section{ii. One Way Anova}

$\mathbf{H o}=$ There is no significant different between the gender in employees with respected to enhance the opinion about the procedure followed in recruitment process.
$\mathbf{H}_{1}=$ There is significant different between the gender of employees with respected the opinion about the procedure followed in recruitment process.

One way anova association difference between the gender of employees with respected to enhance the procedure followed in recruitment process.

\begin{tabular}{|c|c|c|c|c|c|c|c|c|}
\hline \multicolumn{9}{|c|}{ Descriptives } \\
\hline \multicolumn{9}{|c|}{ Educationalqualification } \\
\hline & \multirow[t]{2}{*}{$\mathrm{N}$} & \multirow[t]{2}{*}{ Mean } & \multirow[t]{2}{*}{$\begin{array}{l}\text { Std. } \\
\text { Deviation }\end{array}$} & \multirow[t]{2}{*}{$\begin{array}{l}\text { Std. } \\
\text { Error }\end{array}$} & \multicolumn{2}{|c|}{ 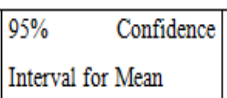 } & \multirow[t]{2}{*}{$\begin{array}{l}\text { Minim } \\
\text { um }\end{array}$} & \multirow[t]{2}{*}{$\begin{array}{l}\text { Maxim } \\
\text { um }\end{array}$} \\
\hline & & & & & $\begin{array}{l}\text { Lower } \\
\text { Bound }\end{array}$ & $\begin{array}{l}\text { Upper } \\
\text { Bound }\end{array}$ & & \\
\hline $\begin{array}{l}\text { veryuse } \\
\text { ful }\end{array}$ & 76 & 1.72 & .858 & .098 & 1.53 & 1.92 & 1 & 4 \\
\hline useful & 23 & 1.87 & .968 & .202 & 1.45 & 2.29 & 1 & 4 \\
\hline \begin{tabular}{|l|} 
Adequa \\
te
\end{tabular} & 7 & 1.86 & .690 & .261 & 1.22 & 2.50 & 1 & 3 \\
\hline poor & 4 & 1.50 & 1.000 & .500 & -.09 & 3.09 & 1 & 3 \\
\hline \begin{tabular}{|l|} 
Total \\
\end{tabular} & 110 & 1.75 & .869 & .083 & 1.59 & 1.92 & 1 & 4 \\
\hline
\end{tabular}

\begin{tabular}{|l|l|l|l|l|l|}
\hline ANOVA & $\begin{array}{l}\text { Sum of } \\
\text { Squares }\end{array}$ & df & $\begin{array}{l}\text { Mean } \\
\text { Square }\end{array}$ & F & Sig. \\
\hline & .710 & 3 & .237 & .307 & .820 \\
\hline $\begin{array}{l}\text { Between } \\
\text { Groups }\end{array}$ & 81.663 & 106 & .770 & & \\
\hline Within Groups & 82.373 & 109 & & & \\
\hline Total &
\end{tabular}

\section{Interpretation:}

The Value Is Significance (2-Tailed) Is 0.820 Which Lesser Than 0.05 At $95 \%$ Confidence Level So Reject The Null Hypothesis (H0) And Accept The Alternate Hypothesis (H1). Hence There Is Association Difference Between The Age Group Of Employees With Respect To The Opinion About The Present Method Followed By The Organization

\section{LIMITATIONS}

This is presented to the reason and inclinations of the respondents, in this manner $100 \%$ of precision can't be assured. The research was done in a constrained ability to center time, where in the assessment couldn't widen the study. The revelations rely upon the fitting reactions given by the laborers, so any error or inclination may be impact the authenticity of the finding.

\section{CONCLUSION}

The research was carried out to provide a clear picture to identify the skills knowledge company of the employee and to 
match of mop them as necessary with their respective job designation. While selecting the candidate to organizations gives importance to marketing knowledge, communication skills and experience of the candidate in the respect field. The employee ready to refer their known ones to the company and they are rewarded by the management. The private organizations maintains good employee relation by conducting various recreation activities and giving them preference by awarding them for their activates.

\section{REFERENCES}

1. Vasanthi, S. \& Rabiyathul Basariya, S. 2019, "Influence of value analysis and cross training in industry", International Journal of Engineering and Advanced Technology, vol. 8, no. 6, pp. 1810-1811.

2. Velvizhi, R., Sri Gowtham, S. \& Jeya Priya, D. 2019, "Examination of early feedbacks for effective product retailing on E-commerce websites", International Journal of Engineering and Advanced Technology, vol. 8, no. 6 Special Issue 2, pp. 703-706.

3. Anuradha, C., Pothumani, S. \& Kavitha, R. 2019, "A novel method towards E-commerce", International Journal of Engineering and Advanced Technology, vol. 8, no. 6 Special Issue 2, pp. 535-538.

4. Thomas, J. \& Rabiyathul Basariya, S. 2019, "A study on the issues of financial ratio analysis", Indian Journal of Public Health Research and Development, vol. 10, no. 3, pp. 1079-1081.

5. Ramachandran, S. \& Rabiyathul Basariya, S. 2019, "Online marketing - study on customer satisfaction and relationship", Indian Journal of Public Health Research and Development, vol. 10, no. 3, pp. 1072-1078.

6. Priya, R., Vinothini, G. \& Cor Jesu, C.D. 2019, "The mentor-protégé relationship for professional growth", Journal of Advanced Research in Dynamical and Control Systems, vol. 11, no. 9 Special Issue, pp. 1110-1119.

7. Jannifer Rani, N., Bina Pani, S. \& Nimisha, N.S. 2019, "A study on money back polices available in LIC", Journal of Advanced Research in Dynamical and Control Systems, vol. 11, no. 9 Special Issue, pp. 833-839.

8. Saillaja, V., Jhansi Rani, K. \& Catherine, R. 2019, "Global marketing management planning and organization", Journal of Advanced Research in Dynamical and Control Systems, vol. 11, no. 9 Special Issue, pp. 489-493.

9. Saillaja, V., Jhansi Rani, K. \& Catherine, R. 2019, "The new phase of marketing information system", Journal of Advanced Research in Dynamical and Control Systems, vol. 11, no. 9 Special Issue, pp. 482-488.

10. Thoufiqulla \& Raju, D.V. 2019, "Perception of indian investor towards investment in mutual funds with special reference to mip funds", Journal of Advanced Research in Dynamical and Control Systems, vol. 11, no. 5, pp. 177-183.

11. Jasmine, K.R.M. \& Basariya, S.R. 2018, "A study on the customers benefits on mutual funds", International Journal of Civil Engineering and Technology, vol. 9, no. 4, pp. 45-48.

12. Vasanthi, S. \& Basariya, S.R. 2019, "Pros and cons of on the job training versus off the job training", International Journal of Scientific and Technology Research, vol. 8, no. 10, pp. 671-674.

13. Pavithra, J. \& Ganesan, M. 2016, "A study on awareness and impact of micro-financial schemes", International Journal of Applied Business and Economic Research, vol. 14, no. 8, pp. 5449-5460.

14. Pavithra, J., Dilli Babu, P. \& Ambuli, T.V. 2014, "A study on budgetary control at Maruti Service Masters, Chennai", International Journal of Applied Business and Economic Research, vol. 12, no. 2, pp. 151-161.

15. Gunaraja, T.M. \& Venkatrama Raju, D. 2018, "Determining factors of organisational climate with reference to leadership styles", International Journal of Mechanical Engineering and Technology, vol. 9, no. 9, pp. 1327-1332.

16. Gunaraja, T.M. \& Venkatrama Raju, D. 2018, "The role of job satisfaction and training of employees in determining organisational climate of a selected industry", International Journal of Civil Engineering and Technology, vol. 9, no. 8, pp. 1266-1269.

17. Aarathy, T.S. \& Raju, D.V. 2018, "Performance appraisal and its effects on employees with respect to it sector in Chennai city", International Journal of Civil Engineering and Technology, vol. 9, no. 6, pp. 1535-1538.
18. Aarathy, T.S. \& Raju, D.V. 2018, "Employee perception towards performance appraisal system in IT sector", International Journal of Mechanical Engineering and Technology, vol. 9, no. 5, pp. 131-135.

19. Porselvi, W., Jublee, D. \& Sivanesan, G. 2018, "A study on factors influencing adoption of technology and innovation in banking industry, tamilnadu, India", International Journal of Mechanical Engineering and Technology, vol. 9, no. 5, pp. 789-800.

20. Akessa, G.M. and Dhufera, A.G., 2015. Factors That Influences Students Academic Performance: A Case of Rift Valley University, Jimma, Ethiopia. Journal of Education and Practice, 6(22), pp.55-63.

21. Miller, G. and Shih, C.C., 1999. A faculty assessment of the academic rigor of on-and off-campus courses in agriculture. Journal of Agricultural Education, 40, pp.57-65.

22. Tsinidou, M., Gerogiannis, V. and Fitsilis, P., 2010. Evaluation of the factors that determine quality in higher education: an empirical study. Quality Assurance in education, 18(3), pp.227-244.

23. Farooq, M.S., Chaudhry, A.H., Shafiq, M. and Berhanu, G., 2011. Factors affecting students' quality of academic performance: a case of secondary school level. Journal of quality and technology management, 7(2), pp.1-14.

24. Fitsilis, P., Gerogiannis, V. and Anthopoulos, L., 2014. Ontologies for software project management: a review. Journal of Software Engineering and Applications, 7(13), p.1096.

25. Adams, J.D. and Jaffe, A.B., 1996. Bounding the effects of R\&D: an investigation using matched establishment-firm data(No. w5544). National bureau of economic research.

\section{AUTHORS PROFILE}

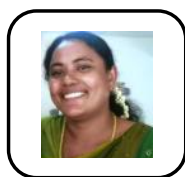

W.Porselvi Assistant Professor, Department Of Science and Humanities, Bharath Institution Of Higher Education And Research, TamilNadu, India

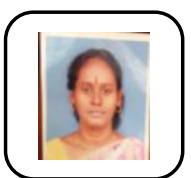

Sumathi Arjunan Assistant Professor, Department Of Science and Humanities, Bharath Institution Of Higher Education And Research,TamilNadu, India.

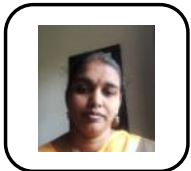

M.M.Shanmuga Priya Assistant Professor, Department Of Science and Humanities,Bharath Institution Of Higher Education And Research,TamilNadu, India 